\title{
Effect of ionic strength, serum albumin and other macromolecules on the maintenance of motility and the surface of mammalian spermatozoa in a simple medium
}

\author{
R. A. P. Harrison, H. M. Dott and G. C. Foster \\ A.R.C. Institute of Animal Physiology, Cambridge, U.K.*
}

\begin{abstract}
Summary. The seminal plasma in sperm suspensions from boar, bull, rabbit, ram and stallion was replaced with simple defined media as completely as possible by a combination of centrifugation through Ficoll and dilution. After this process, motility declined and the cells showed a tendency to agglutinate and/or stick to glass. Varying the ionic strength of the medium had little effect upon these parameters but sperm motility was preserved better in the presence of serum albumin. When a number of purified proteins and other macromolecules were tested individually in this way for their motility-preserving ability, bovine or human serum albumin was consistently the most effective. Defatting the albumin or altering its nature by mild reduction, oxidation or alkylation had little detectable effect on its motility-preserving ability; the protein did not appear to be acting as a chelator of metal ions, for it could not be replaced by EDTA.

The response of the spermatozoa to replacement of seminal plasma varied between species: bull spermatozoa were particularly sensitive and serum albumin had little effect upon their subsequent motility.
\end{abstract}

\section{Introduction}

Mammalian spermatozoa die rapidly after extensive dilution of semen by simple saline media-the 'dilution effect' (see Mann, 1964). The effect seems to result primarily from the lowering of the concentration of the seminal plasma and its replacement by the artificial medium (Emmens \& Swyer, 1948; Blackshaw, 1953; Lindholmer, 1974a). However, spermatozoa are relatively long-lived both in the epididymis and in the female reproductive tract (where they are at a very great dilution); one must therefore assume that these cells are inherently stable but that simple artificial media either exert some damaging effect or lack factors essential for cell viability.

Bredderman \& Foote (1971a) showed that bovine serum albumin can promote bull sperm survival after dilution. Such protective action of high molecular weight compounds, especially serum albumin, in artificial media has also been observed by others (Emmens \& Swyer, 1948; Cheng, Casida \& Barrett, 1949; Blackshaw, 1953; White, 1953; Lindholmer, 1947a), and it has usually been considered to be exerted via replacement or maintenance of the sperm cell's lipoprotein coating, degeneration of which presages cell death (see Mann, 1964). However, there has been no detailed study of this action. We have therefore tested the possibility that the sperm cell coating is eluted in saline media through an ionic strength effect, and we have also investigated the specificity and mode of action of serum albumin's protective effect.

\section{Materials and Methods}

\section{Materials}

Semen. Semen samples were from (i) individual collections from six different crossbred boars; (ii) individual collections from 3 Friesian bulls; (iii) pooled collections from a group of at least 6

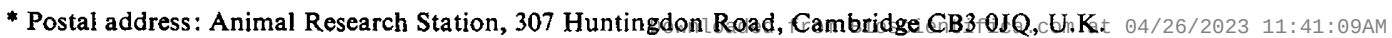


rabbits in the laboratory colony; (iv) pooled collections from at least 4 Suffolk rams; (v) individual collections from 2 stallions (a purebred Welsh Mountain Pony and a Welsh Mountain Pony-Arab crossbred). All semen used was from fertile animals. It was not necessarily always of the highest quality, since we considered it important to assess the responses of representative unselected samples and to look for improvement in motility as well as deterioration. All semen (except that from boar) was collected by artificial vagina, and any gel fraction was removed before use; the boar semen was collected in fractions by the gloved-hand technique, and only the sperm-rich fraction was used. The usual precautions were taken to avoid cold-shock during collection and processing.

Reagents. All chemicals were of the highest purity commercially available, and solutions were made up in glass-distilled deionized water. Unless otherwise stated, bovine serum albumin was the Sigma preparation A4378; this was the purest of a number of commercial preparations as judged by SDS-polyacrylamide gel electrophoresis, and had a normal thiol content $(0.5-0.6 \mathrm{~mol} \mathrm{SH} / \mathrm{mol}$ protein).

Artificial media. The standard medium, henceforth referred to as Medium S, was based on the findings of Bredderman \& Foote (1971b). It contained $20 \mathrm{~mm}-N$-2-hydroxyethylpiperazine- $N^{\prime}-2-$ ethanesulphonic acid (HEPES: Hopkin \& Williams, Chadwell Heath, Essex), $10 \mathrm{~mm}$-glucose, 2 mM- $\mathrm{Na}_{2} \mathrm{HPO}_{4}, 4 \mathrm{mM}-\mathrm{MgCl}_{2}, 2.5 \mathrm{mM}-\mathrm{KOH}$, and $100 \mu \mathrm{g}$ kanamycin sulphate (Sigma London)/ml, and was buffered to $\mathrm{pH} 7 \cdot 5-7 \cdot 55$ with $\mathrm{NaOH}$ (Harrison, 1976); the osmolality, measured by freezingpoint depression, was adjusted with $\mathrm{NaCl}$ to $300-310 \mathrm{mosmol} / \mathrm{kg}$.

In the experiments, modifications were made to Medium $\mathrm{S}$ (such as replacing the $\mathrm{NaCl}$ with sucrose); these are described in the appropriate sections.

\section{Transfer of spermatozoa into artificial media}

Semen samples containing $5-8 \times 10^{8}$ cells were washed by the procedure of Harrison (1976). The wash medium was a solution of $7.5 \%(w / v)$ Ficoll dissolved in whichever test medium was being studied; the osmolality of the wash medium was adjusted by omitting an appropriate quantity of $\mathrm{NaCl}$ or sucrose (see Harrison, 1976). After centrifugation, the volume of the tube contents was reduced to $1 \mathrm{ml}$ and the spermatozoa were resuspended; a $50 \mu \mathrm{l}$ sample was then diluted into $1 \cdot 2 \mathrm{ml}$ of the particular test medium. In this way the seminal plasma concentration in the sperm suspension was reduced to less than $0.1 \%$ (calculated from earlier experiments-Harrison, 1976). All operations were carried out at room temperature (at least $20^{\circ} \mathrm{C}$ ).

\section{Evaluation of spermatozoa and analysis of results}

The diluted sperm suspensions were incubated in the dark at $30^{\circ} \mathrm{C}$ in small tubes open to the air. At various times after dilution two samples $(5 \mu \mathrm{l}$ each) of each suspension were placed on glass slides ('Pre-cleaned, Selected': Arnold R. Horwell Ltd, London) at $30^{\circ} \mathrm{C}$; one was examined as an 'open drop' with dark ground illumination, while the other was examined under a coverslip by phasecontrast microscopy. Both examinations were carried out at $30^{\circ} \mathrm{C}$, simultaneously by two independent observers; the samples had been previously coded and randomized.

Motility was graded on an eight point scale from ' $a$ ' to ' $h$ ' where ' $a$ ' indicated a sample in which all spermatozoa were immotile and ' $h$ ' a sample in which most of the spermatozoa were showing vigorous motility. Samples 'were also scored ('yes'/"no') for head-to-head association ('agglutination') and for adhesion to the glass slide surface ('sticking-to-glass') if these phenomena were exhibited by motile cells.

Because all observations were subjective gradings, non-parametric methods were used to analyse the results. The number of observations of each motility grade (the frequency) was determined for each time and each treatment, and a $\chi^{2}$ test was applied to the frequency distributions to assess the significance of any differences between treatments. A similar approach was used to analyse the observations of agglutination and sticking-to-glass. To check the validity of the analyses of motility, separate $\chi^{2}$ analyses of the frequency of occurrence of ' $a$ ' grades (complete immotility) were also carried out, since there was clearly little likelihood of misgrading these samples; such analyses always confirmed the main analyses. 


\section{Experiments and Results}

\section{Effect of ionic strength and bovine serum albumin}

To study the effect of ionic strength, the $\mathrm{NaCl}$ in Medium $\mathrm{S}$ was replaced partly or wholly by sucrose. This yielded media whose ionic strength was 0.170 (Medium S), 0.109 or 0.033 . (Ionic strength $=\frac{1}{2} \sum m_{i} z_{i}{ }^{2}$, where $m$ is the molality and $z$ the charge of each ionic constitutent.)

In addition, the effect of bovine serum albumin was studied by including various concentrations of the protein in each of these three media. Final concentrations were 0,1 or $10 \mathrm{mg} / \mathrm{ml}$ in Medium $\mathrm{S} ; 0,0 \cdot 3,1,3$ or $10 \mathrm{mg} / \mathrm{ml}$ in the medium of ionic strength $0 \cdot 109 ; 0,1$ or $10 \mathrm{mg} / \mathrm{ml}$ in the medium of ionic strength 0.033 . The experiments were carried out on three different samples each of boar, bull, rabbit and ram semen and on four different samples of stallion semen; spermatozoa were transferred to all eleven media and evaluated after incubation at $30^{\circ} \mathrm{C}$ for 1,3 and $5 \mathrm{~h}$. Media of ionic strength $0 \cdot 109$ were not tested on stallion spermatozoa.

After transfer from seminal plasma to a simple artificial medium, the motility of the spermatozoa from all 5 species declined and the cells showed a tendency to agglutinate and/or stick-to-glass. The degree of the response to the artificial medium varied between species. The motility of ram spermatozoa seemed less affected than that of the other species, but these spermatozoa showed a particular tendency to agglutinate; bull sperm motility, on the other hand, was frequently very poor. The spermatozoa in some boar and rabbit samples appeared less motile under a coverslip than in an open drop, but analysis showed that neither the method of examination nor the period of incubation affected differences observed between media. Therefore all the observations for each species in each medium were pooled.

The effect of ionic strength and albumin on sperm motility are shown in detail in Tables 1 and 2; their effects are summarized in Table 3, which also contains data on agglutination and sticking-toglass. There was no interaction between the two variables.

Table 1. Motility of spermatozoa in a simple medium with respect to ionic strength

\begin{tabular}{|c|c|c|c|c|c|c|c|}
\hline \multirow[b]{2}{*}{ Species } & \multirow{2}{*}{$\begin{array}{l}\text { Ionic } \\
\text { strength }\end{array}$} & \multicolumn{4}{|c|}{$\begin{array}{l}\text { No. of observations of } \\
\text { motility grade }\end{array}$} & \multirow{2}{*}{$\begin{array}{c}\chi^{2} \\
\text { contribution }\end{array}$} & \multirow[b]{2}{*}{ Total $\chi^{2}$} \\
\hline & & $a \quad b \quad c \quad d$ & $\mathrm{e}$ & f & g h & & \\
\hline Boar & $\begin{array}{l}0.033 \\
0.109 \\
0.170\end{array}$ & $\begin{array}{rrrr}2 & 6 & 6 & 4 \\
7 & 10 & 10 & 6 \\
& 2 & 1 & 3 \\
\end{array}$ & $\begin{array}{l}4 \\
9 \\
8\end{array}$ & $\begin{array}{l}16 \\
18 \\
15\end{array}$ & $\begin{array}{ll}10 & 6 \\
24 & 6 \\
18 & 7\end{array}$ & $\begin{array}{l}2 \cdot 9 \\
4 \cdot 2 \\
9 \cdot 6\end{array}$ & $\chi^{2}=16.7,12$ d.f., $0.1<P<0.2$ \\
\hline Bull & $\begin{array}{l}0.033 \\
0.109 \\
0.170\end{array}$ & $\begin{array}{rrrr}11 & 12 & 4 & 8 \\
18 & 13 & 10 & 15 \\
14 & 6 & 6 & 6\end{array}$ & $\begin{array}{l}14 \\
18 \\
14\end{array}$ & $\begin{array}{r}5 \\
13 \\
8 \\
\end{array}$ & 3 & $\begin{array}{l}3 \cdot 2 \\
1 \cdot 6 \\
1 \cdot 8\end{array}$ & $\chi^{2}=6.6,10$ d.f., $0.7<P<0.8$ \\
\hline Rabbit & $\begin{array}{l}0.033 \\
0 \cdot 109 \\
0 \cdot 170\end{array}$ & $\begin{array}{r}1 3 \longdiv { 2 6 } \\
\quad 782 \\
\end{array}$ & $\begin{array}{r}10 \\
15 \\
7\end{array}$ & $\begin{array}{l}24^{\circ} \\
39 \\
24\end{array}$ & $\begin{array}{r}8 \\
19 \\
7 \\
\end{array}$ & $\begin{array}{l}0 \cdot 6 \\
1 \cdot 4 \\
2 \cdot 2\end{array}$ & $\chi^{2}=4.2,8$ d.f., $0.8<P<0.9$ \\
\hline Ram & $\begin{array}{l}0.033 \\
0.109 \\
0.170\end{array}$ & $\begin{array}{rrrr}2 & 5 & 8 & 8 \\
& 2 & 8 & 27 \\
& 3 & 3 & 12 \\
\end{array}$ & $\begin{array}{l}17 \\
28 \\
13\end{array}$ & $\begin{array}{l}12^{r} \\
18 \\
17\end{array}$ & $\begin{array}{l}2 \\
7 \\
5 \\
\end{array}$ & $\begin{array}{l}8 \cdot 1 \\
3 \cdot 3 \\
3 \cdot 5\end{array}$ & $\chi^{2}=14.9,8$ d.f., $0.05<P<0.1$ \\
\hline Stallion & $\begin{array}{l}0.033 \\
0.170\end{array}$ & $\begin{array}{llll}1 & 5 & 12 & 17 \\
4 & 9 & 18 & 15 \\
\end{array}$ & & $\begin{array}{r}14 \\
4 \\
\end{array}$ & $\begin{array}{l}1 \\
2 \\
\end{array}$ & $\begin{array}{l}3.9 \\
3.9\end{array}$ & $\chi^{2}=7.9,4$ d.f., $0.05<P<0.1$ \\
\hline
\end{tabular}

The distribution of motility grades was analysed as a contingency table in the expectation that the distribution would be uniform. The total $\chi^{2}$ indicates the probability that the distribution was not uniform, and the $\chi^{2}$ contribution

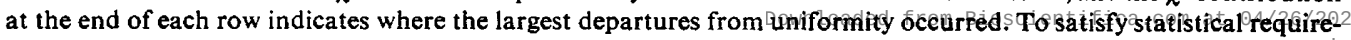
ments, figures in each row of the bracketed columns were summed before analysis. 
Table 2. Motility of spermatozoa in a simple medium with respect to serum albumin concentration

\begin{tabular}{|c|c|c|c|c|c|c|c|}
\hline \multirow[b]{2}{*}{ Species } & \multirow{2}{*}{$\begin{array}{l}\text { Albumin } \\
\text { conc. } \\
(\mathrm{mg} / \mathrm{ml})\end{array}$} & \multicolumn{5}{|c|}{$\begin{array}{l}\text { No. of observations of } \\
\text { motility grade }\end{array}$} & \multirow[b]{2}{*}{ Total $\chi^{2}$} \\
\hline & & a $\quad b \quad c$ & d & e & f & g 1 & \\
\hline \multirow[t]{3}{*}{ Boar } & 0 & $\longdiv { 9 1 0 } 1 0$ & 8 & 8 & 8 & 1 & \multirow{3}{*}{$\chi^{2}=71 \cdot 1,12$ d.f., $P<0.001$} \\
\hline & 1 & 33 & 3 & 11 & 182 & 20 & \\
\hline & 10 & ㄴ. 2,3 & 1 & 61 & 131 & 191 & \\
\hline \multirow[t]{3}{*}{ Bull } & 0 & 19104 & 8 & $9^{r}$ & 4 & & \multirow{3}{*}{$\chi^{2}=18.0,10$ d.f., $0.05<P<0.1$} \\
\hline & 1 & $\begin{array}{lll}12 & 7 & 7\end{array}$ & 9 & 11 & 7 & 1 & \\
\hline & 10 & $\begin{array}{lll}5 & 9 & 4\end{array}$ & 6 & 19 & 8 & 3 & \\
\hline \multirow[t]{3}{*}{ Rabbit } & 0 & $\longdiv { 1 1 1 } \longdiv { 8 }$ & 8 & 15 & $10^{5}$ & 1 & \multirow{3}{*}{$\chi^{2}=71.1,8$ d.f., $P<0.001$} \\
\hline & 1 & 32 & 4 & 82 & 29 & 8 & \\
\hline & 10 & Lـ & & 52 & 272 & 22 & \\
\hline \multirow[t]{3}{*}{ Ram } & 0 & $\longdiv { 1 6 1 1 }$ & 14 & 17 & $5^{r}$ & 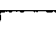 & \multirow{3}{*}{$\chi^{2}=42.0,8$ d.f., $P<0.001$} \\
\hline & 1 & 112 & 15 & 151 & 18 & 2 & \\
\hline & 10 & $\lcm{22} 2$ & 8 & 13 & 18,1 & 10 & \\
\hline \multirow[t]{3}{*}{ Stallion } & 0 & $\sqrt{511} 11$ & 10 & $10^{r}$ & 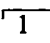 & & \multirow{3}{*}{$\chi^{2}=36.4,8$ d.f., $P<0.001$} \\
\hline & 1 & 312 & 11 & 15 & 6 & 1 . & \\
\hline & 10 & $\longrightarrow$ & 11 & 17 & & 2 & \\
\hline
\end{tabular}

See Table 1 for explanation of analysis.

Table 3. Summary of effects of ionic strength and bovine serum albumin on preservation of sperm motility, and on agglutination and sticking-to-glass

\begin{tabular}{lccc}
\hline & Motility & Agglutination & Sticking-to-glass \\
\hline Ionic strength & & & \\
Boar & 0 & $+^{* * *}$ & 0 \\
Bull & 0 & 0 & 0 \\
Rabbit & 0 & 0 & 0 \\
Ram & $+^{*}$ & 0 & NA \\
Stallion & $-*$ & $+^{* * *}$ & 0 \\
Bovine serum albumin & & & \\
Boar & $+^{* * *}$ & 0 & $+^{* * *}$ \\
Bull & $+^{*}$ & 0 & $-0^{* * *}$ \\
Rabbit & $+^{* * *}$ & $-* *$ & NA \\
Ram & $+^{* * *}$ & 0 & $-* * *$ \\
Stallion & $+^{* * *}$ & 0 & \\
\hline
\end{tabular}

+ indicates a positive correlation-increase in effector leads to increase in parameter; - indicates a negative correlation-increase in effector leads to decrease in parameter; 0 indicates no correlation-no change with effector.

$* 0.05<P<0.1 ; * * 0.01<P<0.02 ; * * * P<0.001$. NA $=$ not assessable.

Varying the ionic strength had little or no effect on motility or sticking-to-glass in any of the species; in every medium a range of scores was always obtained, and if there had been an effect it should have been discernible.

Serum albumin, however, consistently reduced the decline in sperm motility; in most species the effect was marked, although in bull (in which motility was poor after transfer) it was frequently only slight. The effect of serum albumin on agglutination or sticking-to-glass varied between species; in most there was some diminution in these parameters in the presence of albumin, but for boar sticking-to-glass was increased. 


\section{Effect of various macromolecules}

To find out whether the motility-preserving effect of serum albumin was a specific property of this protein, macromolecules of different types were tested individually. Those tested were polyvinylpyrrolidone (a non-protein polymer, mol. wt 30 000-40 000); $\alpha$-lactalbumin and $\beta$-lactoglobulin (two of the major whey proteins in milk); boar bulbo-urethral gland mucin (a mucoprotein); ovalbumin (a glycoprotein); $\gamma$-globulin (a major serum protein component); and serum albumin from two sources, human and bovine. All except the bulbo-urethral gland mucin were obtained commercially and were then purified further: polyvinylpyrrolidone was dialysed exhaustively (Bavister, 1974), $\gamma$-globulin was passed through DEAE-cellulose (Stevenson \& Dorrington, 1970) and the rest were subjected to gel chromatography on Ultrogel AcA44 (LKB). The bulbo-urethral gland mucin was a gift from Dr E. F. Hartree, and had been prepared by ethanolic fractionation of crude mucin. Electrophoretic analysis of the proteins showed the final preparations to be essentially pure.

Each macromolecular species (free of extraneous salts) was dissolved in Medium $\mathrm{S}$ such that it was present at a concentration in excess of $45 \mu \mathrm{M}: 8 \mathrm{mg} / \mathrm{ml}$ for $\gamma$-globulin, $3 \mathrm{mg} / \mathrm{ml}$ for others. The bulbo-urethral gland mucin was an exception; because of its viscous nature, it had to be used at a concentration of $0.5 \mathrm{mg} / \mathrm{ml}(<0.08 \mu \mathrm{M}$-Boursnell, Hartree \& Briggs, 1970).

The media containing the purified macromolecules were tested on spermatozoa from boar (6 replicate experiments) and ram (5 replicate experiments), using as control Medium $S$ without any addition. (All media contained a final concentration of $0.3 \mathrm{mg}$ Ficoll $/ \mathrm{ml}$ derived from the wash medium, but its presence has been ignored because in preliminary experiments Ficoll was found not to affect the parameters under study.) Evaluation was carried out 1, 4 and $7 \mathrm{~h}$ after the spermatozoa were transferred to the various media.

The distribution of motility grades is shown in detail in Table 4. As in the first series of experiments, differences between media were not related to the period of incubation before evaluation or to the method of examination and so all observations for each medium have been pooled. In general, differences between media were not great; most of the macromolecules tested seemed to have some motility-preserving ability. However, bovine serum albumin seemed to preserve motility best overall and human serum albumin was almost as good. Polyvinylpyrrolidone was beneficial to boar spermatozoa but had less effect on ram spermatozoa. $\alpha$-Lactalbumin and $\beta$-lactoglobulin were toxic to boar spermatozoa, motility being worse in their presence than in the control medium; $\alpha$-lactalbumin was also toxic to ram spermatozoa.

None of themacromolecules reduced agglutination; indeed, if anything, they enhanced it. Serum albumin and $\gamma$-globulin had the greatest effect on boar spermatozoa $\left(\chi^{2}=60 \cdot 8,8\right.$ d.f., $\left.P<0.001\right)$,

Table 4. Motility of boar and ram spermatozoa diluted in Medium $\mathbf{S}$ (see text) containing various macromolecules

\begin{tabular}{|c|c|c|c|c|c|c|c|c|}
\hline \multirow[b]{3}{*}{ Macromolecule } & \multicolumn{4}{|c|}{ Boar spermatozoa } & \multicolumn{4}{|c|}{ Ram spermatozoa } \\
\hline & \multicolumn{3}{|c|}{$\begin{array}{l}\text { No. of observations of } \\
\text { motility grade }\end{array}$} & \multirow{2}{*}{$\begin{array}{l}\chi^{2} \\
\text { contribution }\end{array}$} & \multicolumn{3}{|c|}{$\begin{array}{l}\text { No. of observations of } \\
\text { motility grade }\end{array}$} & \multirow{2}{*}{$\begin{array}{c}\chi^{2} \\
\text { contribution }\end{array}$} \\
\hline & $a \quad b$ & c d & $d$ e $f g h$ & & $a b c d$ & e & $\mathrm{f} \mathrm{g} \mathrm{h}$ & \\
\hline None (control) & 38 & 86 & $6 9 \longdiv { 2 }$ & $6 \cdot 7$ & 316 & 15 & $4 \longdiv { 1 }$ & $7 \cdot 8$ \\
\hline Polyvinylpyrrolidone & 43 & 3 & 6884 & $11 \cdot 7$ & 111 & 12 & 114 & $2 \cdot 9$ \\
\hline$\alpha$-Lactalbumin & 168 & 6 & $\begin{array}{lll}4 & 1 & 1\end{array}$ & $29 \cdot 1$ & 1364 & 13 & 3 & $16 \cdot 0$ \\
\hline ß-Lactoglobulin & 136 & 7 & 532 & 14.8 & 3114 & 11 & 73 & $1 \cdot 3$ \\
\hline Mucin & 35 & 78 & 8103 & $4 \cdot 0$ & 112 & 13 & 112 & $3 \cdot 2$ \\
\hline Ovalbumin & 75 & 410 & $\begin{array}{llll}0 & 5 & 4 & 1\end{array}$ & $4 \cdot 3$ & 124 & 9 & 59 & $8 \cdot 0$ \\
\hline$\gamma$-Globulin & 33 & 3 & 81252 & $5 \cdot 9$ & 112 & 10 & 97 & $3 \cdot 4$ \\
\hline Human serum albumin & 35 & 4 & 41361 & $5 \cdot 4$ & 1121 & 8 & 1052 & $3 \cdot 7$ \\
\hline Bovine serum albumin & 24 & 3 & 41661 & $11 \cdot 7$ & 211 & 7 & $16 \lcm{3}$ & $9 \cdot 5$ \\
\hline
\end{tabular}

Total $\chi^{2}=93 \cdot 6,40$ d.f., $P<0.001$

Total $\chi^{2}=55.9,24$ d.f., $P<0.001$ 
while agglutinated cells were found in all samples of ram spermatozoa whatever the medium. There was little observable effect of the different macromolecules on sticking-to-glass.

The comparison of the different macromolecules did not yield clear-cut results. However, if molar concentrations are taken into account, the serum albumins were clearly the most effective at preserving motility, as they were present at a lower molar concentration than the others (apart from mucin). It is of interest that neither $\alpha$-lactalbumin nor $\beta$-lactoglobulin were beneficial, because these are two of the major whey proteins in milk (McKenzie, 1967), which is known to be a good diluent for semen (see Maule, 1962).

\section{Effect of modification of serum albumin}

Serum albumin preparations are heterogeneous even when only one protein species is present (Chen, 1967; Janatova, Fuller \& Hunter, 1968). In an effort to identify the moieties present in the serum albumin that were responsible for its motility-preserving action, purified bovine serum albumin that had been defatted (to remove tightly bound free fatty acids), or defatted and reduced or oxidized (to alter the proportion of mercaptalbumin), or defatted and alkylated (to block the free SH group) was added to Medium $S$ at a concentration of $3 \mathrm{mg} / \mathrm{ml}$. Similar media were prepared containing purified defatted or defatted and oxidized human serum albumin. The modifications were carried out essentially as described by Wallevik (1976). Control media contained purified but unmodified serum albumins.

Spermatozoa from boar ( 6 replicate experiments) and ram ( 5 replicate experiments) were transferred to these media and evaluated after 1,4 and $7 \mathrm{~h}$.

None of the modifications of albumin had any effect on agglutination and sticking-to-glass. Differences between media with respect to sperm motility were marginal and none was statistically significant. Therefore the beneficial effect of serum albumin on sperm motility was clearly not due to any fatty acids associated with the protein; neither was it mediated via the protein's free SH group. The animal species from which the albumin was obtained also seemed unimportant.

\section{Effect of a chelating agent}

Many proteins act as chelating agents; in particular, serum albumin is known to sequester $\mathrm{Ca}^{++}$, $\mathrm{Cu}^{++}, \mathrm{Zn}^{++}$and $\mathrm{Pb}^{++}$(Putnam, 1965). The possibility that serum albumin was acting in this fashion was tested by inclusion of either $1 \mathrm{~mm}$-EDTA, $3 \mathrm{mg}$ commercial bovine serum albumin (Sigma A4378)/ml, or both, in Medium $S$ (preliminary experiments had shown that $1 \mathrm{~mm}$-EDTA had no detrimental effect upon ram spermatozoa). Ram spermatozoa were transferred to these media and evaluated at 1,4 and $7 \mathrm{~h}$. Five replicate experiments were carried out and the distribution of motility grades is given in Table 5 .

EDTA by itself did not affect motility and therefore could not replace albumin, which exhibited its usual motility-preserving action.

Agglutination was clearly reduced by EDTA, both in the presence and the absence of albumin $\left(\chi^{2}=21 \cdot 7,6\right.$ d.f., $\left.0.001<P<0.01\right)$. Moreover, because of the decreased agglutination in the presence of EDTA, sticking-to-glass could be assessed in these samples: both EDTA and albumin reduced

Table 5. Effect of EDTA and bovine serum albumin on the motility of ram spermatozoa in Medium S (see text)

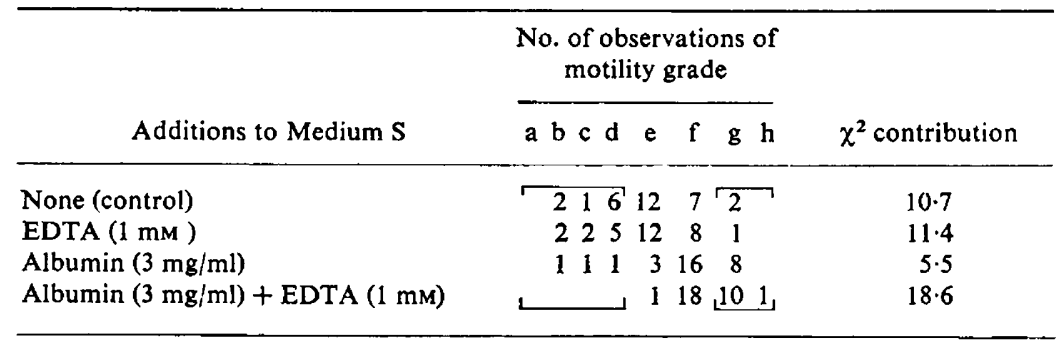

Total $\chi^{2}=46.3,9$ d.f., $P<0.001$ 
sticking-to-glass, possibly in a synergistic fashion $\left(\chi^{2}=33.3,6\right.$ d.f., $\left.P<0.001\right)$. The apparent tendency of EDTA to enhance the motility-preserving action of albumin (see Table 5) may have been due to this reduction of agglutination and sticking-to-glass.

It was concluded that since EDTA could not, of itself, replace serum albumin in preserving sperm motility, albumin was not acting primarily as a chelating agent.

\section{Discussion}

It is clearly impracticable to use the ultimate test of overall sperm function, namely ability to fertilize eggs, at every step of an investigation of sperm survival. However, motility, although not always correlated with fertilizing ability, provides good evidence of some functional integrity, particularly when it persists over many hours. The criterion of persistent motility has been used very widely for many years as a measure of sperm survival, yet the problems associated with motility assessment are not always considered. It would obviously be preferable to use an objective method, such as measurement of velocity and the proportion of motile cells, to give a mathematical description of the motility. Unfortunately, objective methods of assessment could not be used routinely on the samples in our study because of the widespread occurrence of agglutination and sticking-to-glass, although when Quantimet estimates (Dott, 1975) were possible, visual estimates were always confirmed. But visual estimates of sperm motility (e.g. Emmens, 1947) are always subjective and therefore essentially qualitative, i.e. little credence can be placed on the actual quantitative numerical values given, and normal statistical distribution of these values cannot be assumed; moreover, subconscious observer bias is impossible to eliminate, even when samples are coded and randomized before evaluation. Therefore a non-parametric method should be used to analyse the results of visual estimations, so that inherent assumptions about any numerical values assigned to the motility are avoided. Surprisingly, such an approach has rarely been used before, but as can be seen from our results it proved effective and sensitive.

The other two parameters considered, agglutination and sticking-to-glass, were less directly informative as assessments of survival. Both have, by implication, been considered as indicating damage (Bangham \& Hancock, 1955; Dott \& Walton, 1960); however, agglutination can be reversible (see Lindahl, 1960) and we specifically noted that motile cells frequently stick to glass and to each other. That these are separate phenomena seems clear because they occurred separately and were affected differently by treatments. It must be presumed that they are indications of changes of the sperm surface, but their occurrence is not necessarily a measure of a non-physiological or even of a deleterious change.

Only the effects of treatments upon sperm survival have been described, not the actual degree of survival, which varied between species and also between individual semen samples; bull and rabbit samples were especially variable. The cause of this variation is unknown but may be related to the presence of toxic factors in the seminal plasma (see Shannon, 1965; Dott, 1974). Preliminary experiments showed that seminal plasma did have a toxic effect upon spermatozoa; therefore it proved impossible to judge directly the effect of our transfer procedure on survival by, for example, comparing spermatozoa diluted in seminal plasma with spermatozoa subjected to the transfer process and then returned to seminal plasma. Such experiments, though obvious, are difficult to carry out satisfactorily. Nevertheless, the effect of the transfer procedure itself seemed minimal because we observed high levels of motility in ram sperm samples in the presence of albumin, and these high levels persisted throughout the period of the experiment.

Our findings concerning the effect of ionic strength and serum albumin on sperm survival confirm those of workers who have used the simple technique of dilution to (largely) replace seminal plasma. Emmens (1948) and Blackshaw \& Emmens (1951) observed no effect on the motility of diluted semen from rabbit, ram, bull or man when $\mathrm{NaCl}$ was replaced by glucose in the diluent. The beneficial effect of serum albumin has been noted by Emmens \& Swyer (1948), Blackshaw (1953), Bredderman \& Foote (1971a) and Lindholmer (1974a), among others, with respect to the spermatozoa of several species, and it now seems probable that the effect is general to all mammalian spermatozoa.

The mechanism of serum albumin's protective action is, however still unclear, It apparently 
involves a specific property of this protein, but the moiety responsible is not the associated fatty acids nor is it the protein's free sulphydryl group. A chelating action does not appear to be involved, and this is of interest because Lindholmer (1974b) and Johnsen \& Eliasson (1976) have suggested that albumin's action on human spermatozoa is exerted via its chelation of zinc.

While albumin may act by binding to the sperm plasma membrane (Blank, Soo \& Britten, 1976), it does not seem to act by preventing the loss of or by substituting for general cell-coating material (see hypotheses of Emmens \& Swyer, 1948; Blackshaw, 1953). If a general loss of coating material were a primary event in sperm death, differences in ionic strength would be expected to have some effect upon the rate of this loss. Coating material that is attached through ionic bonding will tend to be released by an increase in ionic strength (c.f. Brackett \& Oliphant, 1975); on the other hand, material attached by hydrophobic or non-polar bonding will tend to be bound more firmly at higher ionic strengths as a result of the increased polarity of the external environment. The total lack of observable effect of changes in ionic strength upon the survival of spermatozoa, and the lack of interaction between ionic strength and the albumin effect, suggest strongly that a general loss of coating material is not the primary event in loss of sperm motility caused by dilution or washing.

We should like to thank Mr K. T. Elsome for supplying samples of boar semen, and Dr W. R. Allen for supplying samples of stallion semen. We are very grateful to Dr C. Polge and Dr P. F. Watson for their helpful advice and criticism during the preparation of this paper.

\section{References}

Bangham, A.D. \& Hancock, J.L. (1955) A.new method for counting live and dead bull spermatozoa. Nature, Lond. 176, 656.

BAVISTER, B.D. (1974) The effect of variations in culture conditions on the motility of hamster spermatozoa. J. Reprod. Fert. 38, 431-440.

Blackshaw, A.W. (1953) The motility of ram and bull spermatozoa in dilute suspension.J. gen. Physiol. 36, $449-462$.

Blackshaw, A.W. \& Emmens, C.W. (1951) The interaction of $\mathrm{pH}$, osmotic pressure and electrolyte concentration on the motility of ram, bull and human spermatozoa. J. Physiol., Lond. 114, 16-26.

Blank, M., Soo, L. \& Britten, J.S. (1976) Adsorption of albumin on rabbit sperm membranes. $J$. Membrane Biol. 29, 401-409.

Boursnell, J.C., Hartree, E.F. \& Briggs, P.A. (1970) Studies of the bulbo-urethral (Cowper's)-gland mucin and seminal gel of the boar. Biochem. J. 117, 981-988.

BracketT, B.G. \& Oliphant, G. (1975) Capacitation of rabbit spermatozoa in vitro. Biol. Reprod. 12, 260-274.

Bredderman, P.J. \& FoOTE, R.H. (1971a) Factors stabilizing bull sperm cell volume and prolonging motility at high dilution. Expl Cell Res. 66, 458-464.

Bredderman, P.J. \& FoOTE, R.H. (1971b) Alteration of cell volume in bull spermatozoa by factors known to affect active cation transport. Expl Cell Res. 66, 190-196.

Chen, R.F. (1967) Removal of fatty acids from serum albumin by charcoal treatment. J. biol. Chem. 242, 173-181.

Cheng, P., Casida, L.E. \& Barrett, G.R. (1949) Effects of dilution on motility of bull spermatozoa and the relation between motility in high dilution and fertility. J. Anim. Sci. 8, 81-88.
DorT, H.M. (1974) The effects of bovine seminal plasma on the impedance change frequency and glycolysis of bovine epididymal spematozoa. J. Reprod. Fert. 38, 147-156.

DotT, H.M. (1975) The estimation of the proportion of motile bull spermatozoa in various diluents and a comparison with the proportion eosinophilic. $J$. Reprod. Fert. 45, 47-55.

DotT, H.M. \& Walton, A. (1960) Effects of dilution and washing on ram spermatozoa studied by the flow dialysis technique. J. Reprod. Fert. 1, 350-367.

EMmENS, C.W. (1947) The motility and viability of rabbit spermatozoa at different hydrogen-ion concentrations. J. Physiol., Lond. 106, 471-481.

EMMENs, C.W. (1948) The effect of variations in osmotic pressure and electrolyte concentration on the motility of rabbit spermatozoa at different hydrogen-ion concentrations. J. Physiol., Lond. 107, 129-140.

EMMENS, C.W. \& SWYER, G.I.M. (1948) Observations on the motility of rabbit spermatozoa in dilute suspension. J. gen. Physiol. 32, 121-138.

HARRISON, R.A.P. (1976) A highly efficient method for washing mammalian spermatozoa. J. Reprod. Fert. 48, 347-353.

Janatova, J., Fuller, J.K. \& Hunter, M.J. (1968) The heterogeneity of bovine albumin with respect to sulphydryl and dimer content. J. biol. Chem. 243, 3612-3622.

Johnsen, O. \& Eliasson, R. (1976) Follicular fluid and succinate oxidation by human spermatozoa. Andrologia 8, 283-284.

LindahL, P.E. (1960) Some factors influencing the biological activity of sperm antagglutins. $J$. Reprod. Fert. 1, 3-22.

Lindholmer, C. (1974a) The importance of seminal plasma for human sperm motility. Biol. Reprod. 10, Down533\$542. rom Bioscientifica.com at 04/26/2023 11:41: 09AM via free access 
LINDHOLMER, C. (1974b) Toxicity of zinc ions to human spermatozoa and the influence of albumin. Andrologia 6, 7-16.

McKenzie, H.A. (1967) Milk proteins. Adv. Protein Chem. 22, 55-234.

MANN, T. (1964) The Biochemistry of Semen and of the Male Reproductive Tract. Methuen, London.

MAULE, J.P. (Ed.) (1962) The Semen of Animals and Artificial Insemination. Commonwealth Agricultural Bureaux, Farnham Royal, Bucks.

Putnam, F.W. (1965) Structure and function of the plasma proteins. In The Proteins, Vol. III, pp. 153267. Ed. H. Neurath. Academic Press, New York.
Shannon, P. (1965) Presence of a heat-labile toxic protein in bovine seminal plasma. $J$. Dairy Sci. 48, 1362-1365.

Stevenson, G.T. \& Dorrington, K.J. (1970) The recombination of dimers of immunoglobulin peptide chains. Biochem. J. 118, 703-712.

WALLEVIK, K. (1976) SS-interchanged and oxidized isomers of bovine serum albumin separated by isoelectric focussing. Biochim. biophys. Acta 420, 4256.

White, I.G. (1953) The effect of potassium on the washing and dilution of mammalian spermatozoa. Aust. J. exp. Biol. 31, 193-200.

Received 4 April 1977 